Supporting information for

\title{
Discharge driven nitrogen dynamics in a mesoscale river basin as constrained by stable isotope patterns
}

Christin Mueller $^{1 *}$, Matthias Zink ${ }^{2}$, Ronald Krieg ${ }^{1}$, Michael Rode ${ }^{3}$, Ralf Merz $^{1}$, Luis Samaniego ${ }^{2}$, Kay Knöller ${ }^{1}$

[1] Helmholtz Center for Environmental Research - Department Catchment Hydrology - Stable Isotope Group, Theodor-Lieser-Straße 4, D-06120 Halle (Saale), Germany

[2] Helmholtz Center for Environmental Research - Department Computational Hydrosystems Permoserstraße 15, 04318 Leipzig, Germany

[3] Helmholtz Center for Environmental Research - Department Aquatic Ecosystem Analysis Brückstraße 3a, 39114 Magdeburg, Germany

\section{Contents}

Text S1 Biochemical processes of natural and anthropogenic nitrate sources in Page S2 the N-cycle.

Table S1 Selected nitrogen isotope enrichment factors $(\varepsilon)$ and relation to Page S3 associated nitrate-oxygen ratios 


\section{Text S1}

\section{Biochemical processes of natural and anthropogenic nitrate sources in the $\mathrm{N}$-cycle. Common}

nitrate sources for contemporary central European river systems are the atmosphere as dry and wet deposition, industrial fertilizer or manure as well as treated or untreated wastewater. Besides, gaseous nitrogen can be fixed to organic nitrogen by diazotrophic prokaryotes like cyanobacteria or other microorganisms in soil and streams ${ }^{1}$. In terrestrial systems, biological nitrogen fixation (BNF) rates are nearly balanced with opposed denitrification rates ${ }^{2,3}$ depending on temperature and nutrient supply ${ }^{4}$. The nitrogen cycle is influenced by modern $\mathrm{N}$ sources like synthetic nitrate from the Haber-Bosch process, nitrogen fixation by agricultural practice as well as the combustion of fossil fuels. These anthropogenic sources double the natural rate of terrestrial $\mathrm{BNF}^{2}$. The formed organic-N can be mineralized to ammonium and furthermore nitrified to nitrate. Subsequently, nitrate can be assimilated by plants and as ammonium by microorganisms in the soil and freshwater and thereby are transferred back to organic-N. Irreversible nitrogen removal is possible by anoxic denitrification processes of soil- $\mathrm{NO}_{3}{ }^{-}$into gaseous $\mathrm{N}_{2}$, or by anaerobic microbial ammonium oxidation (anammox $)^{5,6}$. 
Table S1. Selected nitrogen isotope enrichment factors $(\varepsilon)$ and relation to associated nitrateoxygen ratios for certain forming and removing nitrate processes in stream aquatic systems

\begin{tabular}{|c|c|c|}
\hline Process & ${ }^{15} \varepsilon(\%)$ & ${ }^{18} \varepsilon:^{15} \varepsilon$ \\
\hline \multicolumn{3}{|l|}{ Nitrate sources } \\
\hline (Aerobic) nitrification & $\begin{array}{l}0.0 \pm 0.5\left(\mathrm{NH}_{4}^{+} \text {limited }\right)^{7,8} \\
-14 \text { to }-35\left(\mathrm{NH}_{4}^{+} \text {abundant }\right)^{9,10}\end{array}$ & $\begin{array}{l}\text { - } \\
\text { (oxygen not contained in } \\
\text { substrate) }\end{array}$ \\
\hline \multicolumn{3}{|l|}{ Nitrate sinks } \\
\hline (Anaerobic) denitrification & -6 to $-25^{8,11-13}$ & $\begin{array}{l}0.4 \text { to } 0.7 \text { (field } \\
\text { experiment) } \\
\end{array}$ \\
\hline $\begin{array}{l}\text { Anaerobic ammonium } \\
\text { oxidation }\end{array}$ & $\begin{array}{l}23.5 \text { to } 29.1 \text { (batch } \\
\text { experiment) }\end{array}$ & \\
\hline Assimilation in organisms & $\begin{array}{l}\text { medium } \\
\varepsilon_{\text {in }}=2.0 \pm 0.3 \\
\varepsilon_{\text {out }}=1.2 \pm 0.4 \\
\text { intercellular } \\
\varepsilon_{\mathrm{nr}}=26.6 \pm 0.2^{16}\end{array}$ & $\sim 1^{8,10,12,16}$ \\
\hline
\end{tabular}

\section{REFERENCES}

1. Raymond, J.; Siefert, J. L.; Staples, C. R.; Blankenship, R. E., The natural history of nitrogen fixation. Mol Biol Evol 2004, 21, (3), 541-54.

2. Canfield, D. E.; Glazer, A. N.; Falkowski, P. G., The Evolution and Future of Earth's Nitrogen Cycle. Science 2010, 330, (6001), 192-196.

3. Vitousek, P. M.; Menge, D. N. L.; Reed, S. C.; Cleveland, C. C., Biological nitrogen fixation: rates, patterns and ecological controls in terrestrial ecosystems. 2013; Vol. 368.

4. Marcarelli, A. M.; Wurtsbaugh, W. A., Temperature and nutrient supply interact to control nitrogen fixation in oligotrophic streams: An experimental examination. Limnology and Oceanography 2006, 51, (5), 2278-2289.

5. Casciotti, K. L.; Buchwald, C., Insights on the marine microbial nitrogen cycle from isotopic approaches to nitrification. Frontiers in Microbiology 2012, 3, 356.

6. Thamdrup, B., New Pathways and Processes in the Global Nitrogen Cycle. Annual Review of Ecology, Evolution, and Systematics 2012, 43, (1), 407-428.

7. Heaton, T. H. E., Isotopic studies of nitrogen pollution in the hydrosphere and atmosphere: A review. Chemical Geology: Isotope Geoscience section 1986, 59, (0), 87-102.

8. Kendall, C.; Elliott, E. M.; Wankel, S. D., Tracing Anthropogenic Inputs of Nitrogen to Ecosystems. In Stable Isotopes in Ecology and Environmental Science, Blackwell Publishing Ltd: 2008; pp 375-449.

9. Feigin, A.; Shearer, G.; Kohl, D. H.; Commoner, B., The Amount and Nitrogen-15 Content of Nitrate in Soil Profiles from two Central Illinois Fields in a Corn-Soybean Rotation. Soil Science Society of America Journal 1974, 38, (3), 465-471. 
10. Mariotti, A.; Germon, J. C.; Hubert, P.; Kaiser, P.; Letolle, R.; Tardieux, A.; Tardieux, P., Experimental determination of nitrogen kinetic isotope fractionation: Some principles; illustration for the denitrification and nitrification processes. Plant Soil 1981, 62, (3), 413-430.

11. Brandes, J. A.; Devol, A. H.; Yoshinari, T.; Jayakumar, D. A.; Naqvi, S. W. A., Isotopic composition of nitrate in the central Arabian Sea and eastern tropical North Pacific: A tracer for mixing and nitrogen cycles. Limnology and Oceanography 1998, 43, (7), 1680-1689.

12. Deutsch, B.; Liskow, I.; Kahle, P.; Voss, M., Variations in the $\delta 15 \mathrm{~N}$ and $\delta 18 \mathrm{O}$ values of nitrate in drainage water of two fertilized fields in Mecklenburg-Vorpommern (Germany). Aquat. Sci. 2005, 67, (2), 156-165.

13. Houlton, B. Z.; Bai, E., Imprint of denitrifying bacteria on the global terrestrial biosphere. Proceedings of the National Academy of Sciences 2009, 106, (51), 21713-21716.

14. Knöller, K.; Vogt, C.; Haupt, M.; Feisthauer, S.; Richnow, H.-H., Experimental investigation of nitrogen and oxygen isotope fractionation in nitrate and nitrite during denitrification. Biogeochemistry 2011, 103, (1-3), 371-384.

15. Brunner, B.; Contreras, S.; Lehmann, M. F.; Matantseva, O.; Rollog, M.; Kalvelage, T.; Klockgether, G.; Lavik, G.; Jetten, M. S. M.; Kartal, B.; Kuypers, M. M. M., Nitrogen isotope effects induced by anammox bacteria. Proceedings of the National Academy of Sciences 2013, 110, (47), 18994-18999.

16. Karsh, K. L.; Granger, J.; Kritee, K.; Sigman, D. M., Eukaryotic Assimilatory Nitrate Reductase Fractionates $\mathrm{N}$ and $\mathrm{O}$ Isotopes with a Ratio near Unity. Environmental Science \& Technology 2012, 46, (11), 5727-5735. 